\title{
Factors that Sustain Health and Safety Management Practices in the Food Industry
}

\author{
Hazrat Hassan ${ }^{1}$, Qianwei Ying ${ }^{1, *}$, Habib Ahmad ${ }^{2}$ and Sana Ilyas ${ }^{3}$ \\ 1 Business School, Sichuan University, Chengdu 610065, China \\ 2 Hamdard Institute of Management Sciences, Islamabad Campus, Islamabad 44000, Pakistan \\ 3 Department of management science and technology, Business school, Sichuan University, \\ Chengdu 610065, China \\ * Correspondence: yingqw@scu.edu.cn
}

Received: 4 July 2019; Accepted: 21 July 2019; Published: 24 July 2019

check for updates

\begin{abstract}
Due to the significant change in business organizations, scholarly interest has diverted from studying the determinants of financial performance to understanding the environmental activities, sustainability practices, and health and safety management practices. Despite the extensive literature, it is yet to understand either internal or external factors that improve health and safety management practices in SMEs. This research examines the influence of the internal factors-intellectual capital, information technology capabilities (ITC), and entrepreneurial orientation, and the external capabilities-government financial support, institutional pressure, and managerial networking on six health and safety management practices: management commitment, staff training, worker involvement, safety communication and feedback, safety rules and procedures, and safety promotion policies. We researched 410 Pakistani SMEs from the food business industry. The results indicate that intellectual capital significantly improves management commitment, safety communication and feedback, and safety rules and produces; ITC significantly improves management commitment and safety communication and feedback; and entrepreneurial orientation significantly facilitates safety training and worker involvement only. In the external capabilities, government financial support has a significant influence on management commitment, worker involvement, safety rules and policies, and safety promotion policies. Institutional pressure has a significant influence on management commitment, safety training, safety communication, and feedback and safety promotion policies. Managerial networking significantly influences safety training, worker involvement, safety rules and procedures, and safety promotion policies of SMEs. Focusing only on the food industry is the major limitation of this research, this study recommends SMEs to give sufficient attention to their internal and external factors to enhance health and safety management practices. Further implications are discussed.
\end{abstract}

Keywords: intellectual capital; information technology; entrepreneurial orientation; government support; institutional pressure; managerial networking; health and safety management practices; SMEs

\section{Introduction}

Unlike traditional tactics, business organizations are now become environmentally-oriented to support the community, protect the environment, and improve public health, etc. Several reasons have caused this move, for instance, institutional pressure [1-3], environmental turbulence [4], and local community demands $[5,6]$. Therefore, scholarly interest has diverted from studying the determinants of financial performance to understanding the environmental activities, sustainability practices and health, and safety management practices. Until now, research studies have tried their best to examine the factors that influence environmental practices [7-9], sustainability practices [10,11], and health and 
safety management practices $[12,13]$ in developed and emerging economies. However, the results are fragmented and several constraints have existed in the previous studies. Notably, the role of the internal capabilities such as intellectual capital, information technology capabilities (ITC), and entrepreneurial orientation (EO), as well as the external capabilities such as government financial support, institutional pressure, and managerial networking in health and safety management practices (management commitment, staff training, worker involvement, safety communication and feedback, safety rules and procedures, and safety promotion policies) in SMEs of the food industry. The reason for choosing the food industry is that health and safety management practices play a significant role in certain industry because it has a significant influence on community health [14]. Moreover, as pointed out by Clark and Crandall [15], health and safety management practices play a worthy role in every organization, but particularly, in the food industry, and the health and safety culture is very crucial and a need of the day. Moreover, in Pakistan, none of the studies has discussed health and safety management practices in the food industry despite significant pressure by government. Recently, many food industries have been shut down by the Pakistani government because of lack of health and safety practices. Hence, this gives alarming signals to discuss the factors that can facilitate health and safety management practices in the food industry.

In general health and safety management practices deal with both physical and emotional well-being of workers and other people (e.g., outside the organizations) whose health is likely to be unfavorably exaggerated by the firm practices [16]. In this research, health and safety management practices refer to the organizational practices that are performed for protecting the environment, and providing health and safety to workers as well as to other people, e.g., community and societies outside the organization. The variables of the study are shown in Table 1.

The major goal of this research is to uncover the factors that can facilitate health and safety management practices in the food industry. In particular Pakistani food industries very much have a lack of health and safety management practices due to lack of resources, lack of support, and lack of awareness. Additionally, there are several objectives for testing the relationship between internal and external resources and health and safety management practices. First, as pointed out earlier, health and safety management practices have received minor attention in the SMEs sector, since SMEs cannot actively practice health and safety management due to lack of resources and lack of support $[17,18]$. This research encourages and enables them toward health and safety management practices. Second, health and safety management practices have been ignored in Pakistani SMEs. For instance, Zhu et al. [19] argued that due to lack of awareness and lack of support, Pakistani firms are not environmentally oriented. This research fills the gap to identify the most prominent factors that enable the Pakistani food industry to perform health and safety management practices. Third, firms invest enough resources in a variety of factors to spur their environmental, sustainability, and health and safety practices [20]. This research, by examining the internal and external resources, facilitates them (e.g., SMEs) to focus on only significant determinants as well as probably less expensive factors that can configure health and safety management practices. This research helps government authorities who are responsible for health and safety culture and encourages them to configure certain practices in business industries.

The theoretical contributions and practical implications of this study are twofold. For instance, this study tests the relationship between the internal factors, such as intellectual capital, ITC, and entrepreneurial orientation, as well as the external capabilities, such as government financial support, institutional pressure, and managerial networking and health and safety management practices (management commitment, staff training, worker involvement, safety communication and feedback, safety rules and procedures, and safety promotion policies). Based on empirical evidence collected from the food industry, this research suggests significant implications for practicing leaders and practitioners to provide adequate attention to the most prominent factors that boost health and safety management practices. The findings of this research will save financial and nonfinancial resources of SMEs and lead them toward less expensive and less risky factors. Alternatively, the results 
will spur sustainable development in terms of environment and community through the SMEs sector. From a theoretical perspective, this study tests institutional theory [21] and resource dependence theory (RDT) [22,23]. Institutional theory argues three types of pressures, normative, coercive, and mimetic, that influence environmental and social practices of firms [21]. RDT demonstrates the resources existing in the surroundings outside of the central firms and in the guardianship of other businesses [22,23]. Though the theories have been widely debated, they have received minor attention from empirical research of emerging SMEs. This research adds new evidence to the prevailing works and confirms that the connection between internal and external factors and health and safety management practices exists. For instance, as claimed by Annan et al. [12], safety and health practices in organizations are significantly influenced by internal practices, such as leadership and policies, and external pressure of government. The scientific contribution of this research is stated in term of discovering the importance of ITC in health and safety management practices. For instance, this may be the first study to unleash the significance of ITC in health and safety management practices, particularly in the small food industry, as previous studies have had mixed results and have given minor attention to ITC in the small food industry.

\subsection{Underpinning Theory}

This research looks into the role of the internal factors, namely intellectual capital, ITC, and entrepreneurial orientation, and the external factors, namely government financial support, institutional pressure, and managerial networking in health and safety management practices. It is important to consider the theoretical underpinning of both internal and external factors (see Table 1) that can spur health and safety management practices. Two theories, institutional theory and resource dependence theory, are selected to be tested in this research.

\subsection{Institutional Theory}

Organizations have specific explicit value ad philosophy and are the part of the social system, other than having a system for production. The decision-making process of organizations is based on the pattern of cultural values, behaviors, and norms of the external environment $[2,24]$. When all organizations adopt similar kinds of institutionalized activities and decision-making patterns within the same industry, it presents their acceptance toward legitimation [25]. In general, institutional theory works to know about various external forces and factors that influence organizations to adopt or initiate environment related practices that are aligned with health and safety $[21,26]$. Institutional theory describes three types of pressures: normative, coercive, and mimetic pressures. Coercive pressures comprise informal or formal pressures from persuasive organizations on firms' resources and activities [21]. Normative pressures show certain norms and standard dignified by the sustainably that is associated with the environment and environmental-related (e.g., health and safety) activities and practices [27]. Such types of pressure can be sourced by different organizations such as educational institutions, professionals, and associations from the industry that are aligned with the business, nongovernment organization, and the general public [21]. Additionally, sometimes, normative pressures can be effected by suppliers and customers $[1,28]$. Mimetic pressures play a significant role in driving organizations to avoid risk and uncertainty by replicating the structures or procedures of other successful organizations [21]. For instance, if external environmental pressures significantly threaten an organization, it looks for a role model to know how that organization dealt or deals with the external pressures and then applies that procedure to respond to the environmental threats [25]. Particularly, the manufacturing sector around the world faces great pressure from external environments to adopt safety, health, and green supply chain management practices [2,3]. To sum up, this theory focuses on the external pressure of government and communities on business organizations to adopt health and safety management practices. 


\subsection{Resource Dependence Theory}

RDT demonstrates the resources accessibility by a firm in the atmosphere outside and the guardianship of other businesses [22,23]. Organizations that have sufficient resources try to main their power and grip while corporations in need of certain resources try to find alternatives to reduce their dependency [29]. RDT facilitates managers and industries to reduce their dependence on environmental resources. In these situations, despite the physical assets such as machinery, raw material, capital, and labor, customers and dealers are the most precarious assets that should be accomplished efficiently [29-31]. The main theme of RDT is used to explain and understand the adaptation and practices of green supply chain management [13] and health and safety management practices $[32,33]$ for the direct and indirect influence of the stakeholders as well as for dependence on external environmental resources on the focal organizations [34]. In addition, the government and other organizations can enforce and increase pressures on the focal organizations to use pollution-free material in their productions that cannot harm the health of employees and individuals. Additionally, RDT facilitates firms in the implementation and planning of best green practices that are useful for the health and safety process [13]. To summarize, this theory in the present research perspective argues that SMEs lack of resources and support; hence, they rely on external support (e.g., networking and government financial assistance) to configure their operational activities and practices (health and safety management).

Table 1. Operationalization of the Variables.

\begin{tabular}{|c|c|c|}
\hline Variable & Operationalization & Source \\
\hline Intellectual Capital & $\begin{array}{l}\text { The intangible abilities of a firm in the form of human } \\
\text { capital, structural capital, and relational capital used for } \\
\text { competitiveness and performance. }\end{array}$ & Khan et al. [35] \\
\hline ITC & $\begin{array}{l}\text { A firm ability to use technology for operational process, } \\
\text { transactions, and interaction through internet, etc. }\end{array}$ & Peng et al. [36] \\
\hline Entrepreneurial Orientation & $\begin{array}{l}\text { Decision making process of a firm characterized by } \\
\text { innovativeness, proactiveness, and risk taking. }\end{array}$ & Dess and Lumpkin [37] \\
\hline Govt. Financial Support & $\begin{array}{l}\text { Financial support from government banks and } \\
\text { governmental institutions in term of loans and capital. }\end{array}$ & Songling et al. [38] \\
\hline Institutional Pressure & $\begin{array}{l}\text { The external pressures such normative, coercive, } \\
\text { and mimetic pressures that influence firms' } \\
\text { environmental activities. }\end{array}$ & DiMaggio and Powell [21] \\
\hline Managerial Networking & $\begin{array}{l}\text { Top managers' relationship with suppliers, government, } \\
\text { and other businesses. }\end{array}$ & Wang et al. [39] \\
\hline Health and Safety Management & $\begin{array}{l}\text { Deal with both physical and psychological well-being of } \\
\text { employees, workers, and other people (e.g., outside the } \\
\text { organizations) whose health is likely to be affected by the } \\
\text { firm practices. }\end{array}$ & [16] \\
\hline
\end{tabular}

\subsection{Hypotheses Development}

\subsubsection{Internal Factors and Health and Safety Management Practices}

Organizations need to configure their internal management system effective to enhance their safety performance [40]. Safety management practices are unsatisfactory in many SMEs due to a high risk associated with safety management issues as compared to other risks. In general the most significant drivers that facilitate safety management practices in SMEs are efficiency, less risk, market competitiveness, and positive laws, while lack of financial resources, lack of awareness, lack of training for employees, and resistance to change are the major barriers in adoption of safety management practices $[17,18]$. One of the major responsibilities of executives is the safety and health of employees and communities. However, they face problems such as time, people, and money in the adoption of health and safety practices. Hence, management needs to identify the most useful ways of utilizing the resources in an efficient way to encourage and promote safety and health practices [41]. It is the responsibility of the internal management system and leaders to create health and safety (HS) management practices among each department [42]. Heath promotion managerial work in a workplace 
is essential for workers to enhance the sustainability of the organizations, because health-related activities of top managers influence the daily practices of workers in the context of health that consequently changes the organizations [43].

Safety programs are essential factors for successful industries, because successful safety programs provided several benefits to the organizations. Therefore, top managers' commitment to workers and employees is needed for effective implementations of safety and health programs and training [44]. In the rapidly globalizing world, safety performance is a strategic issue for business and non-business industries to become world-class competitors [45]. Therefore, one needs to give sufficient attention to the effective preventive measures of the health and safety environment and workplaces such as hazards assessment, training, clean environmental condition, and other protective equipment [17]. In order to build a good safety culture in an organization, top managers need to divert the attitude of workers towards the adoption of best safety and health practices. This move can be feasible through the promotion of work practices, change in culture, and good housekeeping, etc., where top managers attention is needed to spur safety performance management [46]. Internal management systems and reporting culture toward safety and health should be promoted by managers to enhance safety performance and to encourage environmental practices among workers [47]. Many workers in the organization are not safety orientated due to lack of awareness, and age and gender differences. It is the responsibility of the accountable managers to create an equal safety culture in the organization to enhance safety practices in the workplace [48], because managers cannot identify nor can manage safety and health matters effectively in a workplace if they do not care about their employees and reporting requirement [49].

It has been widely known that in today's economy, the importance of intangible assets such as intellectual capital is more important for organizational performance and sustainability practices as compared to tangible [10]. Furthermore, Evans et al. [50] argued that intellectual capital plays a significant role in health practices especially in the hospital sector. It stimulates health-related activities that are important for organizational performance. A firm with sufficient intellectual capital is able to participate in socially responsible activities as compared to those having a low level of intellectual capabilities [51].

Internet-related activities and technology are considered crucial for supply chain activities and supply chain outcomes. Organizations can diminish the use of things such as electricity, energy, time, and waste production and can increase the speed of logistics and operation to enhance supply chain performance [52]. Unlike other organizations, the SMEs sector is not equipped with sophisticated technology, structured environments, health and safety practices, and environmental practices [53]. Improvement in productivity, efficiency, growth, environmental quality, and better safety practices are linked to technology innovation. Particularly, the SME sector gains benefits from technology innovation when focusing on supply chain processes, products, and design, etc. [54]. Additionally, business model innovation that is interchangeably used for technological innovation is an essential parameter of health care organization and improves health practices among health care organizations [55]. Additionally, IT capability is very crucial for improving health system among health care organizations because now a days innovativeness in health care can be brought through modern technology [56]. Improvement in health practices and safety practices in social organizations can be feasible through new and modern technology systems. In other words, IT reduces the cost and expense of various operational activities to stimulate health practices [57].

To respond to the external environment in the context of sustainability and safety practices, top managers must reconfigure their internal strategic posture [58]. Successful managers need to be involved in innovative practices and training that are helpful for the safety of workers. To enhance the ability of health and safety practices and safety worksites in the organization, top managers need to create a safety training culture, changing workplace culture, and uniform enforcement [18]. The internal strategic posture is often aligned with entrepreneurial activities. For instance, it is argued that managers need to diagnose and grasp new prospects in the sustainability and supply chain culture, 
which needs proactive, innovative, and risk taking behaviors [37]. Through sustainability and social practices, a firm can gain modest sustainable benefits in a dynamic market. However, entrepreneurial behaviors such as innovative, proactive, and risk taking characteristics of top managers are needed for adoption of environmental and sustainability practices [11]. Additionally, Hollos et al. [23] linked the strategic orientation of a firm with sustainability and supply chain practices. Therefore, entrepreneurial orientation may significantly influence the adoption of health and safety management practices. Based on the available evidence, we posit the following hypotheses:

Hypothesis 1 (H1). Intellectual capital significantly improves the six health and safety management practices (management commitment, staff training, worker involvement, safety communication and feedback, safety rules and procedures, and safety promotion policies).

Hypothesis 2 (H2). ITC significantly improves the six health and safety management practices (management commitment, staff training, worker involvement, safety communication and feedback, safety rules and procedures, and safety promotion policies).

Hypothesis 3 (H3). Entrepreneurial orientation significantly improves the six health and safety management practices (management commitment, staff training, worker involvement, safety communication and feedback, safety rules and procedures, and safety promotion policies).

\subsubsection{External Factors and Health and Safety Management Practices}

During the last decades, the beliefs of the community for health services supply by health benefactors have been increasingly swelling and the demand for quality and outcomes is strengthening [59]. This firming claim requires additional financial resources and extra effort of the organization from health systems and health practices [60]. However, the budget constraints and lack of support by various government across the globe toward health services and health practices prevent organizations from effective practices of health. According to Kheni et al. [16] the major reasons of lack of health and safety practices in SMEs are lack of government support, lack of human resource skills, insufficient institutional framework, and insufficient health and safety education.

Government regulations are very necessary for environmental protection. For instance, the government can ban the use of certain raw material to guard the atmosphere, or can diminish supply, or can increase the prices of certain material that can cause environmental pollution. The government further needs to direct the environmental standards of organizations to protect the environment [34]. Especially, institutional theory describes the adoption of environmental practices that lead to safety and health practices in the organization [28]. Particularly in emerging economies, business firms need to build a network with government bodies to avoid fines and other penalties related to environment and operation [28]. Organizations with green practices in Pakistan perhaps believe in health and safety management practices. Institutional theory present two major reasons to follow green practices: (i) through external pressure and rights of government and regulatory bodies such as enforcement of laws, fines, and taxes, and (ii) by proving incentives to adopt effective social and environmental practices [61]. Therefore, institutional pressure is a prominence determinant in the acceptance of supply chain practices and health and safety management practices by business firms.

In the early days, industrial health and safety practices received minor attention of governments and companies engaging in extraordinary pollution and environmental degradation [62]. Considering the serious problems that influence health and safety practices of individuals, employees and workers in factories, industries, and communities, the government has shown its desire to use a mixture of overseas experts and inexpert local labors [16]. The government now holds the responsibility of regulating the health and safety practices of SMEs. Based on current safety policies, the government in emerging economies, particularly in China, has empowered small enterprises to avoid unlawful invention actions and encourage them to report health and safety information (China Economic Net, 
no. 10-27, 2016). Indeed, the existing regulations and standards are the driving forces for workplace health improvement and safety practices but should not be viewed as the only means to achieve health and safety improvement in the business sector. Top managers must improve and reconfigure their internal processes and management system to spur the adoption of health and safety management practices and solutions [63]. Universally standard and low-cost safety management practices have significant values for SMEs. Though the internal resources constraints hamper them from health and safety practices government incentive and support work in certain situations to spur their health and safety practices and activities. Hence, management of enterprises have also emphasized on safety and health strategies [64]. In developing economies such as Pakistan, government holds valued resources that may not be accessible unless firms built a network with government and political bodies [65]. Furthermore, the network of top managers with external bodies and organizations is very helpful in improving producing and health practices [66]. Therefore, we posit the following hypotheses:

Hypothesis 4 (H4). Government financial support significantly improves the six health and safety management practices (management commitment, staff training, worker involvement, safety communication and feedback, safety rules and procedures, and safety promotion policies).

Hypothesis 5 (H5). Institutional pressure significantly improves the six health and safety management practices (management commitment, staff training, worker involvement, safety communication and feedback, safety rules and procedures, and safety promotion policies).

Hypothesis 6 (H6). Managerial networking significantly improves the six health and safety management practices (management commitment, staff training, worker involvement, safety communication and feedback, safety rules and procedures, and safety promotion policies).

\section{Methodology}

\subsection{Sample and Data}

This research was conducted in Pakistan SMEs functioning in the four major cities: Islamabad, Rawalpindi, Lahore, and Peshawar. The reason for choosing these cities was because of the head offices of the majority of firms located in these regions [65]. This research focused on the food sector because firms' health and safety practices are more critical in the food sector as compared to another sector [67]. Another reason is that the food sector of Pakistan has received minor attention from the existing studies. We obtained the list of the registered SMEs from the Islamabad chamber of commerce, Rawalpindi chamber of commerce, Lahore chamber of commerce, and Sarhad chamber of commerce and industry. We distributed 1200 questionnaires among the firms, 300 in each city. An English version questionnaire was prepared because English is the second language of Pakistan and easily understandable. We requested top managers as well as responsible managers (e.g., ones who are aware of strategic planning, organization practices, and performance) to fill the questionnaire. After several follow-ups within two months, we received 438 questionnaires of which only 410 were useable that were included in the analysis. The response rate of $34.17 \%$ was received in this study. The SMEs who helped us in filling the survey are presented in Table 2. The maximum number of firms had 101 to 200 employees while the minimum number of firms had 20 to 50 employees. The majority of the firms started their operation in the last 11 to 30 years while old firms (e.g., above 31 years) were the least in number comparatively. In educational background, the majority of the owners and managers were bachelor to master degree holders. 
Table 2. Characteristics of the Firms.

\begin{tabular}{lcc}
\hline \multicolumn{1}{c}{ Description } & Frequency & Percentage \\
\hline Size of firms & & \\
1. 20-50 employees & 41 & 10.0 \\
2. 51-100 employees & 61 & 14.9 \\
3. 101-150 employees & 104 & 25.4 \\
4. 151-200 employees & 123 & 30.0 \\
5. 201-250 employees & 81 & 19.8 \\
Age of firms & & \\
1. 10 years and less & 97 & 23.7 \\
2. 11-20 years & 111 & 27.1 \\
3. 21 and 30 & 121 & 29.5 \\
4. 31 and above & 81 & 19.8 \\
Managers' Education & & \\
1. Bachelor and below & 118 & 28.8 \\
2. Master & 164 & 40.0 \\
3. MS/MPhil & 108 & 26.3 \\
4. PhD & 20 & 4.9 \\
Total & 410 & 100 \\
\hline
\end{tabular}

\subsection{Measurement of Variables}

\subsubsection{Internal Factors}

ITC: ITC indicates the ability of firms in term of technology and the internet, etc. This research used six items to measure ITC. These items were tested in an empirical study by Peng et al. [36] in the context of SMEs.

Intellectual Capital: Intellectual capital has three major dimensions: human capital, structure capital, and organization capital. Studies have used different measures for intellectual capital. However, this research relied on six items that were validated and tested by Khan et al. [35] in the case of SMEs.

Entrepreneurial orientation: Studies have used various dimensions to measure entrepreneurial orientation. However, the mostly used dimensions are innovativeness, risk-taking, and proactiveness [37,68]. This study relied on six items adopted from the prior study of Liu et al. [68].

\subsubsection{External Factors}

Government Financial support: Government provides various financial incentives to the industrial sector to enhance their survival in the long run. Many governments perceive sustainable development goals, economic growth, and environmental performance in the context of financial incentives. This research used six items adopted from a prior study of Songling et al. [38].

Institutional Pressure: This indicates the pressure and force of government and related institutions to adopt and initiate green practice as well as health and safety practices. Institutional theory describes three major types of pressures: coercive, normative, and mimetic [1]. In this research, we used nine items of which three were related to coercive, three were about normative, and three were used for mimetic pressure.

Managerial Networking: This indicates the relationship or interaction of top managers with external bodies such as suppliers, customers, businesses, and political bodies. Through the network, many firms acquire useful resources. Hence, it is perceived that networking can spur the activities of health and safety in firms. To measure networking, we used three items adopted from Wang et al. [39].

Health and Safety Management Practices: A variety of dimensions and measures has been used for health and safety management practices. However, the mostly used dimensions of health and safety management practices are management commitment, worker involvement, safety training, safety communication and feedback, safety rules and procedures, and safety promotion policies. The measures of these dimensions were adopted from Vinodkumar and Bhasi [69]. 
All the variables were measured using a 5 point Likert scale showing strongly disagree (1) to strongly agree (5).

\subsection{Control Variables}

We controlled the age of firms, size of firms, and educational background of top managers for the purpose of minimizing the chances of spurious results. We found mixed results for each control variable that were discussed in the regression Table 6.

\subsection{Common Method Bias}

The model of this research was tested on a cross-sectional data set where the problem of common method bias (CMB) existed [70]. Hence, it was essential to check CMB in the data. We executed Harman one factor test in SPSS based on principle component analysis technique. The results provided 12 factors, which had their eigenvalues greater than one with the first factor showing only $15.17 \%$ variation, which was less than the cutoff value of $50 \%$. Hence, this showed lack of CMB in the data. Moreover, we also tested the impact of a common latent factor in the confirmatory factor analysis and compared the results. This method also confirmed the findings of the Harman one factor test and ensured that the data were free of CMB.

\subsection{Data Analysis}

Data of this research were passed through several screening tests such as normality and multicollinearity. First, we executed descriptive statistics where mean, standard deviation (S.D.), and data normality were shown (see Table 3). Institutional pressure had the highest mean value of 3.65 and safety rules and the procedure had the lowest mean of 3.48. Institutional pressure also had the highest S.D. of 0.44 , and the lowest S.D. of 0.31 was of managerial networking. Data displayed normal as all the factors had their skewness and kurtosis values in the satisfactory range of \pm 2 [71].

Table 3. Descriptive Statistics.

\begin{tabular}{ccccc}
\hline Variables & Mean & S.D. & Skewness & Kurtosis \\
\hline Intellectual capital & 3.53 & 0.32 & -0.803 & 1.390 \\
ITC & 3.61 & 0.32 & 0.058 & 0.688 \\
Entrepreneurial orientation & 3.55 & 0.33 & -0.070 & 1.078 \\
Government financial support & 3.56 & 0.35 & -0.308 & 1.789 \\
Managerial networking & 3.64 & 0.31 & -0.236 & -0.444 \\
Institutional pressure & 3.65 & 0.44 & -0.468 & 0.268 \\
Management commitment & 3.55 & 0.33 & -0.125 & 1.532 \\
Safety training & 3.56 & 0.34 & -0.306 & 0.787 \\
Worker involvement & 3.57 & 0.39 & 0.623 & 1.308 \\
Safety communication and feedback & 3.56 & 0.38 & -0.071 & -0.026 \\
Safety rules and procedure & 3.48 & 0.38 & -0.038 & 1.356 \\
Safety promotion policies & 3.54 & 0.35 & 0.050 & -0.519 \\
\hline
\end{tabular}

\subsection{Correlations}

Correlations among the variables were checked through Pearson correlation, as shown in Table 4 . The results show that all the internal and external resources were significantly related to the health and safety management practices. Intellectual capital was significantly related to all the six health and safety management practices: management commitment $(r=0.273)$, safety training $(r=0.196)$, worker involvement $(r=0.111)$, safety communication and feedback $(r=0.200)$, safety rules and procedure $(r=0.242)$, and SPP $(r=0.247)$. Similarly, ITC also had a significant relationship with all the six health and safety management practices: management commitment $(r=0.319)$, safety training $(r=0.266)$, worker involvement $(r=0.195)$, safety communication and feedback $(r=0.367)$, safety rules and procedure $(r=0.149)$, and safety promotion policies $(r=0.233)$. The relationship between 
entrepreneurial orientation and all the six health and safety management practices is significant; management commitment $(r=0.190)$, safety training $(r=0.368)$, worker involvement $(r=0.254)$, safety communication and feedback $(r=0.144)$, safety rules and procedure $(r=0.137)$, and safety promotion policies $(r=0.174)$. In the external factors, government financial support had a significant relationship with all the six health and safety management practices: management commitment $(r=0.557)$, safety training $(r=0.266)$, worker involvement $(r=0.267)$, safety communication and feedback $(r=0.156)$, safety rules and procedure $(r=0.382)$, and safety promotion policies $(r=0.505)$. Institutional pressure also showed a significant link with all the six health and safety management practices: management commitment $(\mathrm{r}=0.415)$, safety training $(\mathrm{r}=0.238)$, worker involvement $(r=0.160)$, safety communication and feedback $(r=0.191)$, safety rules and procedure $(r=0.131)$, and safety promotion policies $(r=0.332)$. Finally, the relationship of managerial networking was significant with five of the health and safety management practices, namely management commitment $(r=0.328)$, safety training $(r=0.271)$, worker involvement $(r=0.256)$, safety rules and procedure $(r=0.317)$, and safety promotion policies $(r=0.341)$, but not safety communication and feedback $(r=0.075)$. All the six health and safety management practices were significantly related with each other. However, the relationship between size of firms, age of firms, and educational background and health and safety management practices was mixed. The correlation values were less than 0.80 , displaying nonexistence of multicollinearity threats [72].

\subsection{Reliability}

Cronbach's Alpha of the factors was executed to test the inside steadiness of the items that were loaded on each factor. The value of reliability is recommended above 0.70 [73]. However, Taber [74] also claimed that a reliability value greater than 0.65 also indicates acceptable consistency. Based on these suggestions, our items were reliable as all the factors had satisfactory reliability values, as shown in Table 5: intellectual capital (0.65), ITC (0.67), entrepreneurial orientation (0.70), government financial support (0.70), managerial networking (0.78), institutional pressure (0.71), managerial commitment (0.78), safety training (0.73), worker involvement (0.73), safety communication and feedback (0.70), safety rules and procedure (0.73), and safety promotion and policies $(0.71)$. 
Table 4. Correlation.

\begin{tabular}{|c|c|c|c|c|c|c|c|c|c|c|c|c|c|c|c|}
\hline Variables & Size & Age & Education & 1 & 2 & 3 & 4 & 5 & 6 & 7 & 8 & 9 & 10 & 11 & 12 \\
\hline Size & 1 & & & & & & & & & & & & & & \\
\hline Age & $0.188^{* *}$ & 1 & & & & & & & & & & & & & \\
\hline Education & 0.098 * & 0.004 & 1 & & & & & & & & & & & & \\
\hline 2. ITC & 0.063 & 0.0111 * & $0.184^{* *}$ & $0.127^{* *}$ & 1 & & & & & & & & & & \\
\hline 3. EO & 0.124 * & 0.010 & $0.134^{* *}$ & $0.128 * *$ & $0.348^{* *}$ & 1 & & & & & & & & & \\
\hline 4. GFS & $0.138^{* *}$ & -0.005 & 0.071 & $0.320 * *$ & $0.264^{* *}$ & $0.193^{* *}$ & 1 & & & & & & & & \\
\hline 5. IP & 0.052 & -0.026 & 0.087 & $0.105^{*}$ & $0.154^{* *}$ & -0.038 & $0.288^{* *}$ & 1 & & & & & & & \\
\hline 6. $\mathrm{MN}$ & 0.081 & 0.007 & $0.158^{* *}$ & $0.186^{* *}$ & $0.178^{* *}$ & $0.116^{*}$ & $0.395^{* *}$ & $0.325^{* *}$ & 1 & & & & & & \\
\hline 7. MC & $0.129 * *$ & -0.037 & $0.148^{* *}$ & $0.273^{* *}$ & $0.319 * *$ & $0.190^{* *}$ & $0.557^{* *}$ & $0.415^{* *}$ & $0.328^{* *}$ & 1 & & & & & \\
\hline 8. ST & 0.075 & -0.070 & $0.201^{* *}$ & $0.196^{* *}$ & $0.266^{* *}$ & $0.368^{* *}$ & $0.266^{* *}$ & $0.238^{* *}$ & $0.271^{* *}$ & $0.481^{* *}$ & 1 & & & & \\
\hline 9. WI & $0.171^{* *}$ & -0.038 & $0.148^{* *}$ & $0.111^{*}$ & $0.195^{* *}$ & $0.254^{* *}$ & $0.267^{* *}$ & $0.160 * *$ & $0.256^{* *}$ & $0.628^{* *}$ & $0.568 * *$ & 1 & & & \\
\hline 10. SCF & -0.016 & 0.094 & 0.119 * & $0.200 * *$ & $0.367^{* *}$ & $0.144^{* *}$ & $0.156^{* *}$ & $0.191^{* *}$ & 0.075 & $0.194^{* *}$ & $0.277^{* *}$ & 0.120 * & 1 & & \\
\hline 11. SRP & 0.034 & 0.007 & $0.150 * *$ & $0.242^{* *}$ & $0.149 * *$ & $0.137^{* *}$ & $0.382 * *$ & $0.131^{* *}$ & $0.317^{* *}$ & $0.304^{* *}$ & $0.231 * *$ & $0.199 * *$ & $0.188^{* *}$ & 1 & \\
\hline 12. SPP & 0.075 & -0.037 & 0.064 & $0.247^{* *}$ & $0.233^{* *}$ & $0.176^{* *}$ & $0.505^{* *}$ & $0.332^{* *}$ & $0.341^{* *}$ & $0.349 * *$ & $0.312^{* *}$ & $0.286^{* *}$ & $0.249^{* *}$ & $0.138^{* *}$ & 1 \\
\hline
\end{tabular}

${ }^{* *}$ Correlation is significant at the 0.01 level (2-tailed). ${ }^{*}$ Correlation is significant at the 0.05 level (2-tailed). MC $=$ management commitment, $\mathrm{ST}=$ staff training, $\mathrm{WI}=$ worker involvement, $\mathrm{SCP}=$ safety communication and feedback, SRP $=$ safety rules and procedures, $\mathrm{SPP}=$ safety promotion policies, IC $=$ intellectual capital, ITC $=$ information technology capabilities, $\mathrm{EO}=$ entrepreneurial orientation, $\mathrm{GFS}$ = government financial support, IP = institutional pressure, $\mathrm{MN}$ = managerial networking. 
Table 5. Reliability.

\begin{tabular}{ccc}
\hline Variables & No. of Items & Cronbach \\
\hline Intellectual capital & 6 & 0.65 \\
ITC & 6 & 0.67 \\
Entrepreneurial orientation & 6 & 0.70 \\
Government financial support & 6 & 0.70 \\
Managerial networking & 3 & 0.78 \\
Institutional pressure & 9 & 0.71 \\
Management commitment & 9 & 0.78 \\
Safety training & 6 & 0.73 \\
Worker involvement & 5 & 0.73 \\
Safety communication and feedback & 5 & 0.70 \\
Safety rules and procedure & 5 & 0.73 \\
Safety promotion policies & 5 & 0.74 \\
\hline
\end{tabular}

\subsection{Regression Analysis}

Hypotheses were tested through multiple regression in SPSS, as well as a structural model in AMOS was applied for robustness tests. We found mixed results because some of the internal factors had a significant influence on health and safety management practices while some had an insignificant influence. The same case was for also the external factors that are further discussed below. Therefore, we concluded that all six hypotheses were partially accepted, as are discussed below.

Results of the regression (see Table 6) indicated that in the internal resources, intellectual capital had a significant influence on management commitment $(\beta=0.092, p<0.05)$, insignificant influence on ST $(\beta=0.085, p>0.05)$, insignificant influence on worker involvement $(\beta=0.08, p>0.05)$, significant influence on safety communication and feedback $(\beta=0.174, p<0.01)$, significant influence on safety rules and procedure $(\beta=0.130, p<0.05)$, and an insignificant influence on safety promotion policies ( $\beta=0.085, p>0.05)$. ITC had a significant influence on management commitment $(\beta=0.140, p<0.01)$, insignificant influence on safety training $(\beta=0.085, p>0.05)$, insignificant influence on WI $(\beta=0.066$, $p>0.05)$, significant influence on safety communication and feedback $(\beta=0.363, p<0.01)$, insignificant influence on safety rules and procedure $(\beta=0.005, p>0.05)$, and an insignificant influence on safety promotion policies $(\beta=0.071, p>0.05)$. Entrepreneurial orientation had an insignificant influence on management commitment $(\beta=0.051, p>0.05)$, significant influence on safety training $(\beta=0.307$, $p<0.01)$, significant influence on worker involvement $(\beta=0.205, p<0.01)$, insignificant influence on safety communication and feedback $(\beta=0.033, p>0.05)$, insignificant influence on safety rules and procedure $(\beta=0.044, p>0.05)$, and an insignificant influence on safety promotion policies $(\beta=0.077$, $p>0.05)$. Government financial support had a significant influence on management commitment ( $\beta=0.367, p<0.01)$, insignificant influence on safety training $(\beta=0.060, p>0.05)$, significant influence on worker involvement $(\beta=0.139, p<0.05)$, insignificant influence on safety communication and feedback ( $\beta=0.010, p>0.05)$, significant influence on safety rules and procedure $(\beta=0.293, p<0.01)$, and a significant influence on safety promotion policies $(\beta=0.360, p<0.01)$. Institutional pressure had a significant influence on management commitment $(\beta=0.274, p<0.01)$, significant influence on safety training $(\beta=0.180, p<0.01)$, insignificant influence on worker involvement $(\beta=0.081$, $p>0.05)$, significant influence on safety communication and feedback $(\beta=0.182, p<0.01)$, insignificant influence on safety rules and procedure $(\beta=-0.026, p>0.05)$, and a significant influence on safety promotion policies $(\beta=0.204, p<0.01)$. Managerial networking had an insignificant influence on management commitment $(\beta=0.026, p>0.05)$, significant influence on safety training $(\beta=0.089$, $p<0.05)$, significant influence on worker involvement $(\beta=0.119, p<0.05)$, insignificant influence on safety communication and feedback $(\beta=-0.057, p>0.05)$, significant influence on SRP $(\beta=0.153$, $p<0.01)$, and a significant influence on safety promotion policies $(\beta=0.090, p<0.05)$. 
Table 6. Hypotheses Testing.

\begin{tabular}{lcccccc}
\hline \multicolumn{1}{c}{ Factors } & Model 1 & Model 2 & Model 3 & Model 4 & Model 5 & Model 6 \\
\hline Control factors & MC & ST & WI & SCF & SRP & SPP \\
\hline Size & $0.034^{* *}$ & 0.020 & $0.054^{* * *}$ & -0.015 & 0.006 & 0.023 \\
Age & -0.019 & -0.027 & -0.026 & $0.037^{* *}$ & 0.001 & -0.017 \\
Education & $0.053^{* * *}$ & $0.077^{* * *}$ & $0.060^{* * *}$ & $0.054^{* *}$ & $0.065^{* * *}$ & 0.023 \\
Main factors & & & & & & \\
Size & 0.014 & 0.004 & $0.038^{* *}$ & -0.017 & -0.009 & 0.002 \\
Age & -0.016 & -0.026 & -0.025 & 0.029 & 0.005 & -0.012 \\
Education & 0.019 & $0.041^{* *}$ & 0.030 & 0.021 & $0.040^{* *}$ & -0.010 \\
IC & $0.092^{* *}$ & 0.085 & 0.008 & $0.174^{* * *}$ & $0.130^{* *}$ & 0.085 \\
ITC & $0.140^{* * *}$ & 0.085 & 0.066 & $0.363 * * *$ & 0.005 & 0.071 \\
EO & 0.051 & $0.307^{* * *}$ & $0.205^{* * *}$ & 0.033 & 0.044 & 0.077 \\
GFS & $0.367^{* * *}$ & 0.060 & $0.139^{* * *}$ & 0.010 & $0.293^{* * *}$ & $0.360^{* * *}$ \\
IP & $0.274^{* * *}$ & $0.180^{* * *}$ & 0.081 & $0.182^{* * *}$ & -0.026 & $0.204^{* * *}$ \\
MN & 0.026 & $0.089^{* *}$ & $0.119^{* *}$ & -0.057 & $0.153^{* * *}$ & $0.090^{* *}$ \\
$\mathrm{R}^{2}$ & 0.426 & 0.259 & 0.167 & 0.181 & 0.203 & 0.324 \\
$\mathrm{R}^{2}$ change & 0.387 & 0.209 & 0.115 & 0.161 & 0.180 & 0.313 \\
F statistic & 44.911 & 18.771 & 9.203 & 13.206 & 15.058 & 30.826 \\
\hline
\end{tabular}

Note: ${ }^{* *}=$ Significant at $(p<0.05), * * *=$ Significant at $(p<0.001), \mathrm{MC}=$ management commitment, $\mathrm{ST}=$ staff training, WI $=$ worker involvement, $\mathrm{SCP}=$ safety communication and feedback, $\mathrm{SRP}=$ safety rules and procedures, $\mathrm{SPP}=$ safety promotion policies, IC $=$ intellectual capital, ITC $=$ information technology capabilities, EO = entrepreneurial orientation, GFS = government financial support, IP = institutional pressure, $\mathrm{MN}$ = managerial networking.

$\mathrm{R}$ square indicated that both internal and external capabilities brought a $44.91 \%$ change in management commitment, $18.77 \%$ change in safety training, $9.2 \%$ change in worker involvement, $13.21 \%$ change in safety communication and feedback, $15.06 \%$ change in safety rules and procedures, and $30.83 \%$ change in safety promotion policies in the existence of the control variables size of SMEs, age of ventures, and educational background.

\subsection{Robustness}

To improve the validity and generalizability of the results, we executed the model and hypotheses in AMOS via a structural model as robustness. In the structural model (See Figure 1), all the paths were tested at a time via a single model while in regression, we executed a separate model for each dependent variable. The results of the structural model were significantly matched with regression results. However, there was a minor variation in the $\mathrm{R}$ square values, as shown in Table 7 . To summarize, we have presented the major findings of the research in Table 8.

Table 7. Robustness Checks.

\begin{tabular}{ccccccc}
\hline Factors & MC & ST & WI & SCF & SRP & SPP \\
\hline Size & 0.014 & 0.004 & $0.038^{* * *}$ & -0.017 & -0.009 & 0.002 \\
Age & -0.016 & -0.026 & -0.025 & 0.029 & 0.005 & -0.012 \\
Education & $0.019^{* *}$ & $0.041^{* *}$ & 0.030 & 0.021 & $0.040^{* *}$ & -0.010 \\
IC & $0.092^{* *}$ & 0.085 & 0.008 & $0.174^{* * *}$ & $0.130^{* *}$ & 0.085 \\
ITC & $0.140^{* * *}$ & 0.085 & 0.066 & $0.363^{* * *}$ & 0.005 & 0.071 \\
EO & $0.051^{* * *}$ & $0.307^{* * *}$ & $0.205^{* * *}$ & 0.033 & 0.044 & 0.075 \\
GFS & $0.367^{* * *}$ & $0.060^{* * *}$ & $0.139^{* * *}$ & 0.010 & $0.293^{* * *}$ & $0.360^{* * *}$ \\
IP & $0.274^{* * *}$ & $0.180^{* * *}$ & $0.081^{* * *}$ & $0.182^{* * *}$ & -0.026 & $0.204^{* * *}$ \\
MN & 0.026 & $0.89^{* * *}$ & $0.119^{* * *}$ & -0.057 & $0.153^{* * *}$ & $0.090^{* * *}$ \\
$R^{2}$ & 0.30 & $0.18^{*}$ & 0.10 & 0.16 & 0.14 & 0.22 \\
\hline
\end{tabular}

Note: ${ }^{* *}=$ Significant at $(p<0.05),{ }^{* * *}=$ Significant at $(p<0.001), \mathrm{MC}=$ management commitment, $\mathrm{ST}=$ staff training, WI $=$ worker involvement, $\mathrm{SCP}=$ safety communication and feedback, SRP = safety rules and procedures, $\mathrm{SPP}=$ safety promotion policies, IC $=$ intellectual capital, ITC $=$ information technology capabilities, EO = entrepreneurial orientation, GFS = government financial support, $\mathrm{IP}=$ institutional pressure, $\mathrm{MN}=$ managerial networking. 


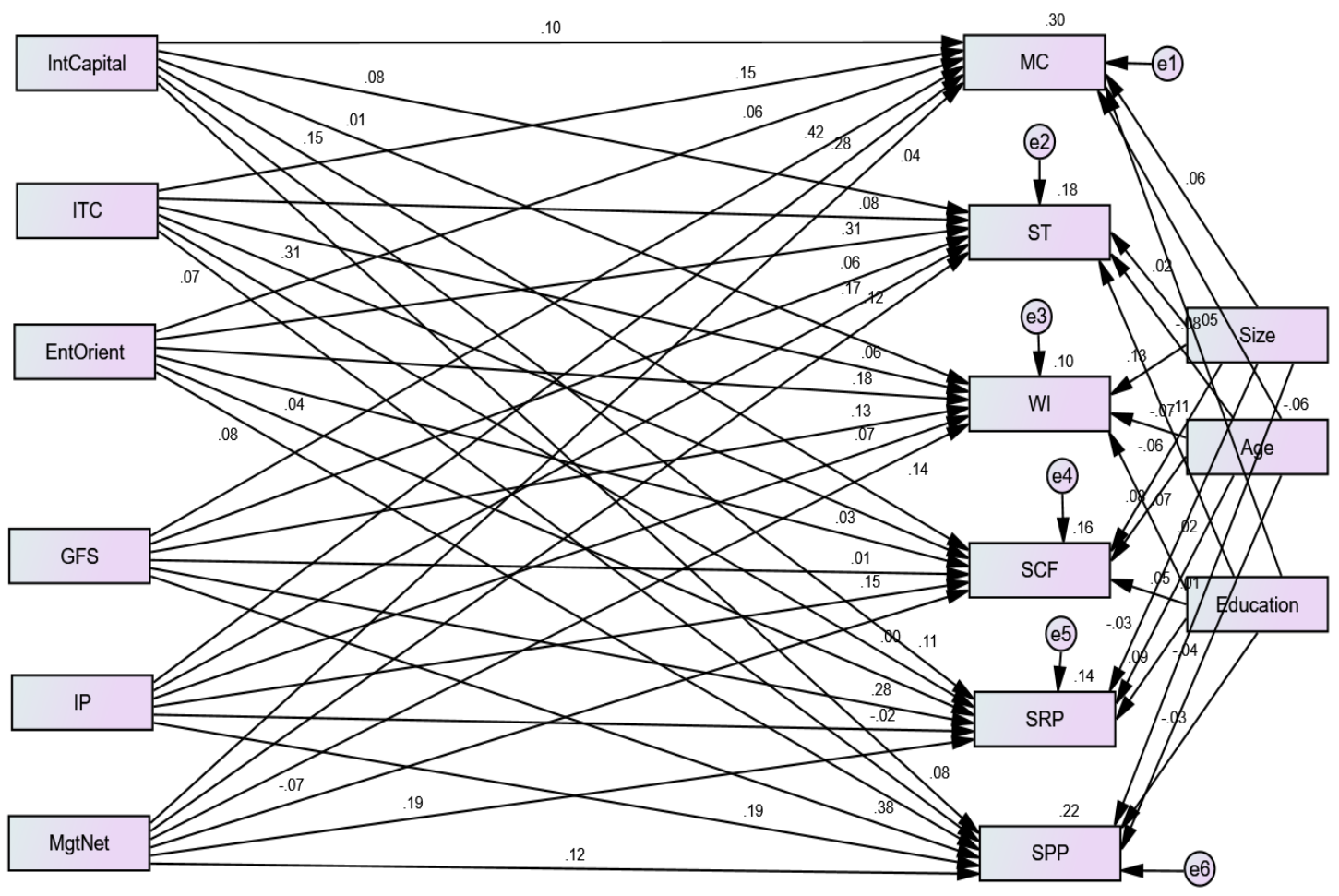

Figure 1. Structural Model.

Table 8. Summary of Major Findings.

\begin{tabular}{ccccccc}
\hline Factors & Model 1 & Model 2 & Model 3 & Model 4 & Model 5 & Model 6 \\
\hline & MC & ST & WI & SCF & SRP & SPP \\
\hline IC & $\uparrow * *$ & $\uparrow$ & $\uparrow$ & $\uparrow * * *$ & $\uparrow * *$ & $\uparrow$ \\
ITC & $\uparrow^{* * *}$ & $\uparrow$ & $\uparrow$ & $\uparrow * * *$ & $\uparrow$ & $\uparrow$ \\
EO & $\uparrow$ & $\uparrow * * *$ & $\uparrow^{* * *}$ & $\uparrow$ & $\uparrow$ & $\uparrow$ \\
GFS & $\uparrow^{* * *}$ & $\uparrow$ & $\uparrow^{* *}$ & $\uparrow$ & $\uparrow^{* * *}$ & $\uparrow * * *$ \\
IP & $\uparrow * * *$ & $\uparrow^{* * *}$ & $\uparrow$ & $\uparrow * * *$ & $\downarrow$ & $\uparrow * * *$ \\
MN & $\uparrow$ & $\uparrow * *$ & $\uparrow * *$ & $\downarrow$ & $\uparrow * * *$ & $\uparrow * *$ \\
\hline
\end{tabular}

Note: $\uparrow=$ improves, $\downarrow=$ declines, ${ }^{* * *}=$ significant $(p<0.001),{ }^{* *}=$ significant $(p<0.05)$. MC $=$ management commitment, $\mathrm{ST}=$ staff training, $\mathrm{WI}=$ worker involvement, $\mathrm{SCP}=$ safety communication and feedback, $\mathrm{SRP}=$ safety rules and procedures, SPP $=$ safety promotion policies, $\mathrm{IC}=$ intellectual capital, $\mathrm{ITC}=$ information technology capabilities, $\mathrm{EO}=$ entrepreneurial orientation, GFS = government financial support, $\mathrm{IP}=$ institutional pressure, $\mathrm{MN}=$ managerial networking.

\section{Discussion}

This research tested the impact of internal resources such as intellectual capital, ITC, entrepreneurial orientation, and external resources such as government financial support, institutional pressure, and managerial networking on health and safety management practices. Though several studies attempted to determine the relationship, the results were fragmented due to several reasons. Moreover, most studies focused on institutional pressure, networking, and innovative activities that can spur health and safety management practices. However, studies have not yet touched the links between internal capabilities and external capabilities and health and safety management practices. Moreover, the existing studies have not tested the relationship discriminately via statistical methods, particularly in emerging SMEs. This research is an attempt to determine where the role of each internal capability, namely intellectual capital, ITC, and entrepreneurial orientation, and each external capability, such as government financial support, institutional pressure, and managerial networking has tested in health and safety management practices. This research tested institutional theory and RDT using empirical evidence collected through a structured questionnaire from emerging SMEs. We added new evidence 
to the aforementioned theories and scrutinized new factors that can lead SMEs toward health and safety management practices.

For instance, we scrutinized that the internal capabilities such as intellectual capital and ITC as well as the external capabilities such as government financial support and institutional pressure significantly improve health and safety management practices in term of management commitment, safety communication and feedback, and safety rules and procedure. Our findings match several studies where intellectual capital was deemed a significant predicator of environmental and social performance [10,51], and additionally was in line with Evans et al. [50] who argued that intellectual capital plays a significant role in health practices especially in the hospital sector. It stimulates health-related activities that are important for organizational performance. ITC significantly improves health and safety management practices in terms of management commitment and safety communication and feedback only, which is consistent with Didonet and Díaz [54], who revealed that advanced technology configures the operational process of firms that is helpful for environmental safety and social protection. Our results match a recent study conducted in China by Sui et al. [75], who argued that a technology-based information system is a crucial tool for good health and safety management practices in the business sector. Entrepreneurial orientation significantly helps in the improvement of safety training and worker involvement only, which is consistent with Marshall et al. [76], who described that entrepreneurial activities help firms in social, safety, and green environmental practices. Similarly, Namagembe et al. [77] also indicated that firms must improve their entrepreneurial orientation to configure their green supply chain practices and environmental protection. Government financial support is a significant predictor of management commitment, worker involvement, safety rules and procedures, and safety promotion policies. Our findings support several existing research studies, such as Wolf [34], Zhu et al. [28], and Zailani et al. [61], who scrutinized that government support is a significant predictor of high health and safety management practices. Particularly, in emerging economies such as Pakistan, SMEs have a lack of financial resources. Therefore, having sufficient financial support of government enables them to perform health and safety management practices effectively. Institutional pressure significantly influences health and safety management practices of SMEs in term of management commitment, safety training, safety communication and feedback, and safety promotion policies. Our findings favor institutional theory, which states the pressure of external bodies on firms to adopt health and safety management practices [21]. This research revealed that IP affects health and safety management practices in SMEs. Similarly, Chu et al. [1] also concluded that external pressures from institutions are significantly aligned with health and safety management practices of SMEs in emerging economies. Managerial networking significantly facilitates SMEs in the improvement of health and safety management practices such as safety training, worker involvement, safety rules and procedures, and safety promotion and policies. The finding is in line with Yuan et al. [66] who demonstrated that external relationship and networking of top managers stimulates their interest of health and safety management practices. We confirmed that managerial networking significantly improves health and safety management practices in the emerging market Pakistan.

\section{Implications for Practices}

This research has unleashed the importance of the internal capabilities; intellectual capital, ITC, entrepreneurial orientation, and external resources such as government financial support, institutional pressure, and managerial networking in health and safety management practices that suggests several significant implications for practicing managers, practitioners, and top managers of SMEs. This research enables them to give sufficient attention to the most significant internal and external predictors of health and safety management practices. For instance, this research revealed that in the internal capabilities, intellectual capital significantly improves management commitment, safety communication and feedback, and safety rules and produces, ITC significantly improves management commitment and safety communication and feedback, and entrepreneurial orientation significantly 
facilitates safety training and worker involvement only. In the external capabilities, government financial support has a significant influence on management commitment, worker involvement, safety rules and policies, and safety promotion policies. Institutional pressure has a significant influence management commitment, safety training, safety communication and feedback, and safety promotion policies. Managerial networking significantly influences safety training, worker involvement, safety rules and procedures, and safety promotion policies of SMEs. Considering the mixed results where most of the health and safety management practices are influenced by both internal and external capabilities, we recommended top managers of SMEs to spur both internal and internal capabilities. None of the internal and external factors significantly decrease health and safety management practices in SMEs. Hence, insignificant predictors should not be discouraged and ignored in SMEs. In other words, Pakistani SMEs must give sufficient attention to the internal and external significant predictors to perform satisfactory health and safety management practices. These are the health and safety management practices that contribute to sustainable development in term of community and environment. Alternatively, these practices improve profitability and enhance SMEs performance in the long run. SMEs needs to promote intellectual capabilities, ITC, and entrepreneurial orientation to configure health and safety management practices. Similarly, they also need to build a network with external bodies and government in order to acquire necessary resources that may be needed for health and safety management practices. As pointed out by Anwar et al. [65] in Pakistan, many valuable resources are possessed by the government, which can be gained through a positive network with government and political bodies. The findings are not only limited to only Pakistan, but other emerging and developed countries can get benefits of this research. For instance, studies have reported a lack of environmental, health, and safety management practices in emerging and developed SMEs $[17,18]$. This research discovers the most momentous prognosticators of health and safety management practices of SMEs. This research helps small businesses to boost their health and safety management practices through the significant internal and external capabilities rather investing a huge amount of money and resources in other factors that may probably not provide satisfactory health and safety management results. This research also encourages Small and Medium Enterprises Authority (SMEDA) and environmental protection agencies to facilitate SMEs in health and safety management practices that in turn add to sustainable development and economic propensity.

\section{Limitations and Future Research}

Despite the complex model, adequate sample, and significant implications, this research is not free of limitations. For instance, this study identified the important internal and external factors influencing the health and safety management practices in the food industry. The related parties can take advantage of the findings of the study to recognize and alleviate the problem in the organizations. The study also pointed out that top-managers were the critical roles in the organizations and external environment to foster health and safety practices. Therefore, top managers have to take responsibility for sustaining health and safety management practice. Moreover, there were some limitations to this study. Only the food industry was investigated in this study, which could not represent all the industries. Further, six health and safety management practices were selected for the investigation. What were the rationales of selecting these six health and safety management practices? The authors have to provide sufficient evidence to support the choice of these six elements.

In a future study, more industries are suggested to be investigated to ensure that the findings could be applied to all sectors of SMEs. The internal and external factors are recommended to be examined in more specific factors as the factors here were a bit general. If specific factors are extracted from current factors for the investigation, the results might provide a clear direction for the organizations to improve the health and safety management practices. Maybe all these need to be included as the limitations of the study.

Additionally, this research is tested in the emerging market Pakistan, only from specific cities in one geographical area/country only (i.e., limited generalizability or representativeness); future 
researchers need to extend this model in other countries to avoid the only of limited interest for an international readership. We tested the model on a cross-sectional data set, which is often criticized for being common method bias. Researchers are encouraged to conduct an in-depth interview and collect longitudinal data to articulate the findings in a better way. This research only tested the importance of three internal capabilities and three external capabilities in health and safety management practices. Future researchers can test other relevant factors that have been ignored particularly in emerging economies in the literature of health and safety management practices. For instance, internal financial capital and financial resources can be considered toward health and safety management practices. In a recent study, Seman et al. [78] claimed that green innovation mediates the relation between green supply chain management and environmental practices. Probably, green innovative and green supply chain management practices mediate the link between internal and external capabilities and health and safety management practices. Moreover, the model can be tested on empirical evidence collected from emerging and developing economies to unleash more useful insights.

Author Contributions: H.H. has developed the idea and have worked on original writing. Q.Y. has reviewed the paper and supervised throughout the work. H.A. helped in the questionnaire, resource management and data collection. S.I. helped in data analysis and interpretation.

Funding: This work was supported by the National Natural Science Foundation of China [71373167], Youth Fund Project of Humanities and Social Sciences of the Ministry of Education of People's Republic of China (18YJC790204), Social Science Key Project of Sichuan Province of China (SC18A006) and the research fund from Sichuan University (SKSYL201822, 2018hhf-47, 2013SCU04A32).

Conflicts of Interest: The authors have no conflict of interest.

\section{References}

1. Chu, S.H.; Yang, H.; Lee, M.; Park, S. The Impact of Institutional Pressures on Green Supply Chain Management and Firm Performance: Top Management Roles and Social Capital. Sustainability 2017, 9, 764. [CrossRef]

2. Gualandris, J.; Kalchschmidt, M.G.M. Customer pressure and innovativeness: Their role in sustainable supply chain management. J. Purch. Supply Manag. 2014, 20, 92-103. [CrossRef]

3. Walker, H.; Di Sisto, L.; McBain, D. Drivers and barriers to environmental supply chain management practices: Lessons from the public and private sectors. J. Purch. Supply Manag. 2008, 14, 69-85. [CrossRef]

4. Yang, Y.; Lau, A.K.; Lee, P.K.; Yeung, A.C.; Cheng, T.E. Efficacy of China's strategic environmental management in its institutional environment. Int. J. Oper. Prod. Manag. 2019, 39, 138-163. [CrossRef]

5. Chen, J.K.; Zorigt, D. Managing occupational health and safety in the mining industry. J. Bus. Res. 2013, 66, 2321-2331. [CrossRef]

6. Page, K.M.; Lamontagne, A.D.; Louie, A.M.; Ostry, A.S.; Shaw, A.; Shoveller, J.A. Stakeholder perceptions of job stress in an industrialized country: Implications for policy and practice. J. Public Health Policy 2013, 34, 447-461. [CrossRef] [PubMed]

7. Chuang, S.-P.; Huang, S.-J. The effect of environmental corporate social responsibility on environmental performance and business competitiveness: The mediation of green information technology capital. J. Bus. Ethics 2018, 150, 991-1009. [CrossRef]

8. Chuang, S.-P.; Huang, S.-J. Effects of business greening and green IT capital on business competitiveness. J. Bus. Ethics 2015, 128, 221-231. [CrossRef]

9. Molla, A.; Cooper, V.; Pittayachawan, S. The Green IT Readiness (G-Readiness) of Organizations: An Exploratory Analysis of a Construct and Instrument. Commun. Assoc. Inf. Syst. 2011, 29, 67-96. [CrossRef]

10. De Villiers, C.; Sharma, U. A critical reflection on the future of financial, intellectual capital, sustainability and integrated reporting. Crit. Perspect. Account. 2017. [CrossRef]

11. Foerstl, K.; Reuter, C.; Hartmann, E.; Blome, C. Managing supplier sustainability risks in a dynamically changing environment-Sustainable supplier management in the chemical industry. J. Purch. Supply Manag. 2010, 16, 118-130. [CrossRef] 
12. Annan, J.-S.; Addai, E.K.; Tulashie, S.K. A Call for Action to Improve Occupational Health and Safety in Ghana and a Critical Look at the Existing Legal Requirement and Legislation. Saf. Health Work 2015, 6, 146-150. [CrossRef] [PubMed]

13. Sarkis, J.; Zhu, Q.; Lai, K.-H. An organizational theoretic review of green supply chain management literature. Int. J. Prod. Econ. 2011, 130, 1-15. [CrossRef]

14. Al-Kandari, D.; Al-abdeen, J.; Sidhu, J. Food safety knowledge, attitudes and practices of food handlers in restaurants in Kuwait. Food Control 2019, 103, 103-110. [CrossRef]

15. Clark, J.; Crandall, P.; Reynolds, J. Exploring the influence of food safety climate indicators on handwashing practices of restaurant food handlers. Int. J. Hosp. Manag. 2019, 77, 187-194. [CrossRef]

16. Kheni, N.A. Impact of Health and Safety Management on Safety Performance of Small and Medium-Sized Construction Businesses in Ghana. Ph.D. Thesis, Loughborough University, Leicestershire, UK, 2008.

17. Unnikrishnan, S.; Iqbal, R.; Singh, A.; Nimkar, I.M. Safety management practices in small and medium enterprises in India. Saf. Health Work 2015, 6, 46-55. [CrossRef] [PubMed]

18. Gillen, M.; Kools, S.; McCall, C.; Sum, J.; Moulden, K. Construction managers' perceptions of construction safety practices in small and large firms: A qualitative investigation. Work 2004, 23, 233-243. [PubMed]

19. Zhu, Q.; Geng, Y.; Sarkis, J. Shifting Chinese organizational responses to evolving greening pressures. Ecol. Econ. 2016, 121, 65-74. [CrossRef]

20. Ferrero, G.; Bichai, F.; Rusca, M. Experiential Learning through Role-Playing: Enhancing Stakeholder Collaboration in Water Safety Plans. Water 2018, 10, 227. [CrossRef]

21. DiMaggio, P.J.; Powell, W.W. The Iron Cage Revisited: Institutional Isomorphism and Collective Rationality in Organizational Fields. Am. Sociol. Rev. 1983, 48, 147-160. [CrossRef]

22. Pfeffer, J.; Salancik, G.R. The External Control of Organizations: A Resource Dependence Perspective; Stanford University Press: Palo Alto, CA, USA, 2003.

23. Hollos, D.; Blome, C.; Foerstl, K. Does sustainable supplier co-operation affect performance? Examining implications for the triple bottom line. Int. J. Prod. Res. 2012, 50, 2968-2986. [CrossRef]

24. Scott, W.R. The Adolescence of Institutional Theory. Adm. Sci. Q. 1987, 32, 493-511. [CrossRef]

25. Williams, Z.; Lueg, J.E.; Taylor, R.D.; Cook, R.L. Why all the changes? An institutional theory approach to exploring the drivers of supply chain security (SCS). Int. J. Phys. Distrib. Logist. Manag. 2009, 39, 595-618. [CrossRef]

26. De Grosbois, D. Corporate social responsibility reporting in the cruise tourism industry: A performance evaluation using a new institutional theory based model. J. Sustain. Tour. 2016, 24, 245-269. [CrossRef]

27. Khalifa, M.; Davison, M.; Davison, R. SME adoption of IT: The case of electronic trading systems. IEEE Trans. Eng. Manag. 2006, 53, 275-284. [CrossRef]

28. Zhu, Q.; Sarkis, J.; Lai, K.-H. Institutional-based antecedents and performance outcomes of internal and external green supply chain management practices. J. Purch. Supply Manag. 2013, 19, 106-117. [CrossRef]

29. Sheu, J.-B. Green Supply Chain Collaboration for Fashionable Consumer Electronics Products under Third-Party Power Intervention-A Resource Dependence Perspective. Sustainability 2014, 6, 2832-2875. [CrossRef]

30. Hillman, A.J.; Withers, M.C.; Collins, B.J. Resource Dependence Theory: A Review. J. Manag. 2009, 35, 1404-1427. [CrossRef]

31. Lai, K.-H.; Wong, C.W.; Lam, J.S.L. Sharing environmental management information with supply chain partners and the performance contingencies on environmental munificence. Int. J. Prod. Econ. 2015, 164, 445-453. [CrossRef]

32. Nunez, I.; Prieto, M. The effect of human capital on occupational health and safety investment: An empirical analysis of S panish firms. Hum. Resour. Manag. J. 2019, 29, 131-146. [CrossRef]

33. Rocha, R.S. Institutional effects on occupational health and safety management systems. Hum. Factors Ergon. Manuf. Serv. Ind. 2010, 20, 211-225. [CrossRef]

34. Wolf, J. The relationship between sustainable supply chain management, stakeholder pressure and corporate sustainability performance. J. Bus. Ethics 2014, 119, 317-328. [CrossRef]

35. Khan, S.Z.; Yang, Q.; Waheed, A. Investment in intangible resources and capabilities spurs sustainable competitive advantage and firm performance. Corp. Soc. Responsib. Environ. Manag. 2019, 26, 285-295. [CrossRef] 
36. Peng, J.; Quan, J.; Zhang, G.; Dubinsky, A.J. Mediation effect of business process and supply chain management capabilities on the impact of IT on firm performance: Evidence from Chinese firms. Int. J. Inf. Manag. 2016, 36, 89-96. [CrossRef]

37. Dess, G.G.; Lumpkin, G.T. The Role of Entrepreneurial Orientation in Stimulating Effective Corporate Entrepreneurship. Acad. Manag. Perspect. 2005, 19, 147-156. [CrossRef]

38. Songling, Y.; Ishtiaq, M.; Anwar, M.; Ahmed, H. The Role of Government Support in Sustainable Competitive Position and Firm Performance. Sustainability 2018, 10, 3495. [CrossRef]

39. Wang, Z.; Ye, F.; Tan, K.H. Effects of managerial ties and trust on supply chain information sharing and supplier opportunism. Int. J. Prod. Res. 2014, 52, 7046-7061. [CrossRef]

40. Zaira, M.M.; Hadikusumo, B.H. Structural equation model of integrated safety intervention practices affecting the safety behaviour of workers in the construction industry. Saf. Sci. 2017, 98, 124-135. [CrossRef]

41. O'Toole, M. The relationship between employees' perceptions of safety and organizational culture. J. Saf. Res. 2002, 33, 231-243. [CrossRef]

42. Milne, J.; Lalonde, A. Patient safety in women's health-care: Professional colleges can make a difference. The Society of Obstetricians and Gynaecologists of Canada MOREOB program. Best Pract. Res. Clin. Obstet. Gynaecol. 2007, 21, 565-579. [CrossRef]

43. Dellve, L.; Eriksson, A. Health-Promoting Managerial Work: A Theoretical Framework for a Leadership Program that Supports Knowledge and Capability to Craft Sustainable Work Practices in Daily Practice and during Organizational Change. Societies 2017, 7, 12. [CrossRef]

44. Cohen, A. Factors in successful occupational safety programs. J. Saf. Res. 1977, 9, 168-178.

45. Dağdeviren, M.; Yüksel, I. Developing a fuzzy analytic hierarchy process (AHP) model for behavior-based safety management. Inf. Sci. 2008, 178, 1717-1733. [CrossRef]

46. Beriha, G.; Patnaik, B.; Mahapatra, S.; Padhee, S. Assessment of safety performance in Indian industries using fuzzy approach. Expert Syst. Appl. 2012, 39, 3311-3323. [CrossRef]

47. Miceli, M.P.; Near, J.P. Whistleblowing: Reaping the benefits. Acad. Manag. Perspect. 1994, 8, 65-72. [CrossRef]

48. Breslin, F.C.; Polzer, J.; MacEachen, E.; Morrongiello, B.; Shannon, H. Workplace injury or "part of the job"?: Towards a gendered understanding of injuries and complaints among young workers. Soc. Sci. Med. 2007, 64, 782-793. [CrossRef] [PubMed]

49. Azaroff, L.S.; Levenstein, C.; Wegman, D.H. Occupational Injury and Illness Surveillance: Conceptual Filters Explain Underreporting. Am. J. Public Health 2002, 92, 1421-1429. [CrossRef] [PubMed]

50. Evans, J.M.; Brown, A.; Baker, G.R. Intellectual capital in the healthcare sector: A systematic review and critique of the literature. BMC Health Serv. Res. 2015, 15, 556. [CrossRef]

51. Barrena-Martinez, J.; López-Fernández, M.; Romero-Fernández, P.M. The link between socially responsible human resource management and intellectual capital. Corp. Soc. Responsib. Environ. Manag. 2019, 26, 71-81. [CrossRef]

52. Shafique, M.N.; Rashid, A.; Bajwa, I.S.; Kazmi, R.; Khurshid, M.M.; Tahir, W.A. Effect of IoT Capabilities and Energy Consumption behavior on Green Supply Chain Integration. Appl. Sci. 2018, 8, 2481. [CrossRef]

53. Organization, W.H. Global strategy on occupational health for all: The way to health at work. In Recommendation of the Second Meeting of the WHO Collaborating Centres in Occupational Health, Beijing, China, 11-14 October 1994; World Health Organization: Geneva, Switzerland, 1995.

54. Didonet, S.R.; Díaz, G. Supply Chain Management Practices as a Support to Innovation in SMEs. J. Technol. Manag. Innov. 2012, 7, 91-109. [CrossRef]

55. Hwang, J.; Christensen, C.M. Disruptive Innovation in Health Care Delivery: A Framework for Business-Model Innovation. Health Aff. 2008, 27, 1329-1335. [CrossRef] [PubMed]

56. Khatri, N. Building IT capability in health-care organizations. Health Serv. Manag. Res. 2006, 19, 73-79. [CrossRef] [PubMed]

57. Bates, D.W.; Cohen, M.; Leape, L.L.; Overhage, J.M.; Shabot, M.M.; Sheridan, T. Reducing the Frequency of Errors in Medicine Using Information Technology. J. Am. Med. Inform. Assoc. 2001, 8, 299-308. [CrossRef] [PubMed]

58. Beske, P.; Seuring, S. Putting sustainability into supply chain management. Supply Chain Manag. Int. J. 2014, 19, 322-331. [CrossRef] 
59. Schwartz, R.W.; Pogge, C. Physician leadership is essential to the survival of teaching hospitals. Am. J. Surg. 2000, 179, 462-468. [CrossRef]

60. Bordignon, M.; Turati, G. Bailing out expectations and public health expenditure. J. Health Econ. 2009, 28, 305-321. [CrossRef]

61. Eltayeb, T.K.; Hsu, C.-C.; Zailani, S.H.M.; Hsu, C.; Tan, K.C. The impact of external institutional drivers and internal strategy on environmental performance. Int. J. Oper. Prod. Manag. 2012, 32, 721-745.

62. Dumett, R. Disease and mortality among gold miners of Ghana: Colonial government and mining company attitudes and policies, 1900-1938. Soc. Sci. Med. 1993, 37, 213-232. [CrossRef]

63. Welch, L.S.; Russell, D.; Weinstock, D.; Betit, E. Best practices for health and safety technology transfer in construction. Am. J. Ind. Med. 2015, 58, 849-857. [CrossRef]

64. Wang, Q.; Mei, Q.; Liu, S.; Zhang, J. Analysis of Managing Safety in Small Enterprises: Dual-Effects of Employee Prosocial Safety Behavior and Government Inspection. BioMed Res. Int. 2018, 2018, 6482507. [CrossRef] [PubMed]

65. Anwar, M.; Rehman, A.U.; Shah, S.Z.A. Networking and new venture's performance: Mediating role of competitive advantage. Int. J. Emerg. Mark. 2018, 13, 998-1025. [CrossRef]

66. Yuan, J.; Yi, W.; Miao, M.; Zhang, L. Evaluating the Impacts of Health, Social Network and Capital on Craft Efficiency and Productivity: A Case Study of Construction Workers in China. Int. J. Environ. Res. Public Health 2018, 15, 345. [CrossRef] [PubMed]

67. Webb, M.; Morancie, A. Food safety knowledge of foodservice workers at a university campus by education level, experience, and food safety training. Food Control 2015, 50, 259-264. [CrossRef]

68. Liu, S.S.; Luo, X.; Shi, Y.-Z. Integrating customer orientation, corporate entrepreneurship, and learning orientation in organizations-in-transition: An empirical study. Int. J. Res. Mark. 2002, 19, 367-382. [CrossRef]

69. Vinodkumar, M.; Bhasi, M. Safety management practices and safety behaviour: Assessing the mediating role of safety knowledge and motivation. Accid. Anal. Prev. 2010, 42, 2082-2093. [CrossRef]

70. Podsakoff, P.M.; Organ, D.W. Self-Reports in Organizational Research: Problems and Prospects. J. Manag. 1986, 12, 531-544. [CrossRef]

71. George, D. SPSS for Windows Step by Step: A Simple Study Guide and Reference, 17.0 update, 10/e; Pearson Education: Delhi, India, 2011.

72. Anwar, M. Business Model Innovation and Smes Performance-Does Competitive Advantage Mediate? Int. J. Innov. Manag. 2018, 22, 1850057. [CrossRef]

73. Tavakol, M.; Dennick, R. Making sense of Cronbach's alpha. Int. J. Med Educ. 2011, 2, 53-55. [CrossRef]

74. Taber, K.S. The use of Cronbach's alpha when developing and reporting research instruments in science education. Res. Sci. Educ. 2018, 48, 1273-1296. [CrossRef]

75. Sui, Y.; Ding, R.; Wang, H. An integrated management system for occupational health and safety and environment in an operating nuclear power plant in East China and its management information system. J. Clean. Prod. 2018, 183, 261-271. [CrossRef]

76. Marshall, D.; McCarthy, L.; McGrath, P.; Claudy, M. Going above and beyond: How sustainability culture and entrepreneurial orientation drive social sustainability supply chain practice adoption. Supply Chain Manag. Int. J. 2015, 20, 434-454. [CrossRef]

77. Namagembe, S.; Sridharan, R.; Ryan, S. Green supply chain management practice adoption in Ugandan SME manufacturing firms: The role of enviropreneurial orientation. World J. Sci. Technol. Sustain. Dev. 2016, 13, 154-173. [CrossRef]

78. Seman, N.A.A.; Govindan, K.; Mardani, A.; Zakuan, N.; Saman, M.Z.M.; Hooker, R.E.; Ozkul, S. The mediating effect of green innovation on the relationship between green supply chain management and environmental performance. J. Clean. Prod. 2019, 229, 115-127. [CrossRef]

(C) 2019 by the authors. Licensee MDPI, Basel, Switzerland. This article is an open access article distributed under the terms and conditions of the Creative Commons Attribution (CC BY) license (http://creativecommons.org/licenses/by/4.0/). 